\title{
NUTRIENT RETENTION IN SURFACE FLOW CONSTRUCTED WETLAND IN AGRICULTURAL LAND IN LATVIA
}

Linda GRINBERGA, Latvia University of Agriculture, Faculty of Environment and Civil Engineering, Department of Environmental Engineering and Water Management, Akademijas Str. 19, Jelgava, LV-3001, Latvia, linda.grinberga@llu.lv (corresponding author) Ainis LAGZDINS, Latvia University of Agriculture, Faculty of Environment and Civil Engineering, Department of Environmental Engineering and Water Management, Akademijas Str. 19, Jelgava, LV-3001, Latvia, ainis.lagzdins@llu.lv

The research site consists of a pilot-scale surface flow constructed wetland at the farm Mezaciruli located in Zalenieki County, Jelgava Region, in the middle part of Latvia. The constructed wetland was installed in June 2014 to improve water quality in agricultural catchment and examine nutrient retention at the constructed wetland receiving surface and drainage runoff. The constructed wetland's surface area of 0.37 ha corresponds to $0.5 \%$ of the total catchment area. During the observation period of 32 months (2014-2017) water quality parameters such as total suspended solids (TSS), nitrate-nitrogen $\left(\mathrm{NO}_{3}-\mathrm{N}\right)$, ammonium-nitrogen $\left(\mathrm{NH}_{4}-\mathrm{N}\right)$, total nitrogen (TN), orthophosphate-phosphorus ( $\left.\mathrm{PO}_{4}-\mathrm{P}\right)$, and total phosphorus (TP) were monitored twice a month using a grab sample approach. Retention efficiency for monitored water quality parameters was calculated based on their concentrations at the inlet and out let. The monitoring results obtained during this study showed a reduction within the constructed wetland for all examined parameters. The concentrations of $\mathrm{NO}_{3}-\mathrm{N}, \mathrm{NH}_{4}-\mathrm{N}$ and $\mathrm{TN}$ were reduced on average by $13 \%, 15 \%$ and $16 \%$, respectively. $\mathrm{PO}_{4}-\mathrm{P}$ and TP concentrations were reduced on average by $38 \%$ and $36 \%$, respectively. Total suspended solids were reduced by $31 \%$ at the outlet of the constructed wetland. However, in some cases, an increase in nutrient concentrations in water leaving the constructed wetland was observed. Therefore, there is a need for further research to investigate causes of such increase.

Keywords: Agricultural runoff, constructed wetland, surface flow

\section{INTRODUCTION}

Agricultural lands can cause a diffuse pollution load on the environment due to release of nutrients from cultivated areas (Jordan et al, 2003. Lagzdins et al, 2012. Greenway, 2017). Latvia is located in a humid climate zone with a longterm average annual precipitation of $667 \mathrm{~mm}$ (LEGMC, 2017) where precipitation exceeds evapotranspiration resulting in average annual runoff of $245 \mathrm{~mm}$ (Ziverts, 2004). During the research period average monthly precipitation amount in the Dobele meteorological station ranged from 14 to $79 \mathrm{~mm}$ in 2014, from 4 to $93 \mathrm{~mm}$ in 2015, from 16 to $95 \mathrm{~mm}$ in 2016 and from 22 to $71 \mathrm{~mm}$ in 2017 (LEGMC, 2017). The research site is located in the area with intensive agricultural production, which can cause increased nutrient load on the environment and open watercourses when compared with other regions in Latvia. However, Deelstra et al (2014) have described the role of catchment scale and groundwater contribution on nutrient losses as well as effect of othersite specific factors influencing nu trient leaching processes.

One type of measures to reduce pollution burden to the environment from agricultural lands are naturally -based methods. Adapting nutrient retention processes from natural systems to manmade treatment plants is a sustainable way to control the pollution close to the place of its origin. Six different components of sustainable drainage systems (Woods Ballard et al. 2015) are included in a Regulatory Act No. 600 of Cabinet of Ministers (2014) in Latvia. Nutrient and sediment retention within the Regulatory Act is recommended through sedimentation ponds, two-stage ditches, bottom dams, stream meandering, controlled drainage and constructed wetlands, which all perform primarily on the biological, chemical and physical processes based on water self-purification principles. This study evaluated the efficiency of surface flow constructed wetland, exploited to retain nitrogen and phosphorous substances and suspended solids from surface and drainage runoff. Number of studies has shown that constructed wetlands have a positive effect on nutrient removal from surface runoff (Hsu et al, 2011. Galanopolos et al, 2016. Šereš et al, 2017.) and drainage runoff from agricultural lands (Maynard et al, 2009. Vymazal et al, 2015).

Constructed wetlands provide additional valuable benefits for the environment and human besides nutrient retention (Keddy, 2010). The shape of the surface flow constructed wetland in the farm Mezaciruli is made in irregular shape to visually fit in a natural countryside landscape, complementing the landscape diversity. Landscape diversity is one of the 
biodiversity types and accomplishes overall environmental value. The same concept was reported by Hefting (2013) who described that small wetlands enhance biodiversity at the landscape as well as regional scale. Wetlands increase biodiversity by creating water - plant habitat (Hsu, 2011) as wetlands are the most productive habitats on the Earth (Keddy, 2010). There are two islands in the wetland distributing the water flow and providing a place of residence for birds. The farmer is using a certain amount of water from the wetland for greenhouse irrigation during a summer low water period. Appropriate chemical water quality analysis was performed before water supply into drip irrigation system. Presence of nitrate - nitrogen in the irrigation water allowed to reduce the amount of fertilization required for optimal crop growth.

The main goal of this research was to investigate the ability of the constructed wetland to reduce diffuse pollution from agricultural areas in Latvia. The surface flow constructed wetland allowed us to analyse nutrient retention in the open stream that collects surface and drainage runoff from the agriculturally dominant catchment under the site specific meteorological conditions.

\section{MONITORING SITE DESCRIPTION}

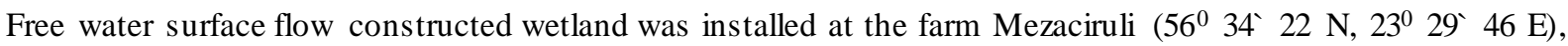
Zalenieki county, Jelgava region, Latvia (LGIA, 2017). The study site is located within the Nitrate Vulnerable Zones designated according to the criteria of the EU Nitrates Directive (EC, 1991), since intensity of agricultural activities throughout the Zemgale region is relatively high. According to the geos patial information of the Digital Drainage Cadastre prepared by State Limited Liability Company "Ministry of Agriculture Real Estate" the entire catchment area is artificially drained using clay drain pipes, collectors and open ditches and is intensively used for agricultural activities (Figure 1). Agricultural land is used mainly as arable land to grow agricultural crops. The catchment area is dominated by fertile haplic luvisols and mollic luvisols with approximation to the classification of World Reference Base for Soil Resources (Karklins, 2016). Topography in the Zemgale region is relatively flat, therefore the risk of occasional surface runoff occurrence is low (Lagzdins, 2012).

The constructed wetland was built by transforming a $240 \mathrm{~m}$ long part of an existing open drainage ditch within a distance of $100 \mathrm{~m}$ before inflow into the Eglone River. Disposition of the constructed wetland on the existing ditch is related to the position of a water level control and measuring structure, which ensure appropriate water level and prevent downstream areas from flooding. It is not allowed to flush the road culvert during the spring foods while raising the water level in the open ditch. Therefore, hydrologic calculations taken in the consideration included maximum spring flood and summer-autumn flow rate with appropriate probability of occurrence. The average annual summer flow rate of the existing ditch is $2.63 \mathrm{l} \mathrm{s}^{-1}$. Optimal performance of the existing drainage systems in the upstream area is ensured through providing the drainage outflow pipes at the level $0.2 \mathrm{~m}$ above the normal water level of the wetland.

The catchment area of the constructed wetland was measured precisely using the geospatial information of the Digital Drainage Cadastre. The catchment area of the constructed wetland is 73.6 ha (SLS, 2014). Several previous studies suggest different wetland surface area/catchment area ratio for effective nutrient reduction. For example, 0.5 to $2 \%$ range of wetland surface area/catchment area ratio is approved for Iowa CREP wetlands (Crumpton et al, 2014), while 0.5 to $4 \%$ range is suggested by Owenius and van der Nat (2011). In this study the surface area of the constructed wetland/catchment area ratio was $0.5 \%$. In order to ensure the optimal ratio 0.27 ha of agricultural land was flooded. Normal water level in the constructed wetland was set in the level of $12.40 \mathrm{~m}$ in the Baltic Height System.

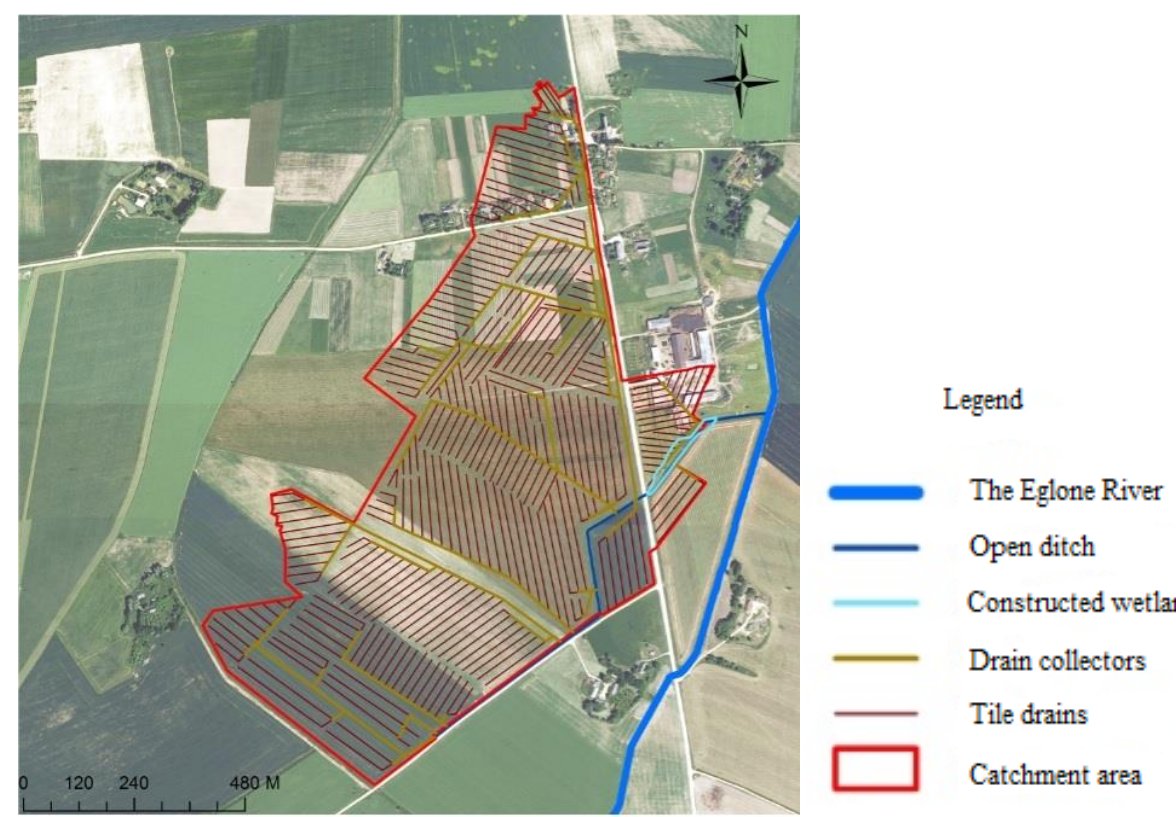

Figure 1. Catchment area and constructed wetland in a farm Mezaciruli. Author: M. Medne. 
The width of the surface flow constructed wetland is in range between 6 and $42 \mathrm{~m}$. The wetland is functionally divided into two parts with a maximu $\mathrm{m}$ water depth of $2.10 \mathrm{~m}$ at the inflow part to facilitate sedimentation proces ses and a shallower part at the outflow part with a maximum water depth of $1.40 \mathrm{~m}$ for nutrient transformation processes. The surface area of the deep section at the inflow and more shallow section at the outflow part is 0.29 ha and 0.08 ha, respectively.

\section{METHODS}

The study includes 33 calendar months during the time period from June, 2014 to July, 2017. The water quality monitoring was carried out continuously during the entire study period. However, monitoring results obtained during the six month period were excluded due to external influence. For the time period from March, 2016 until July, 2016 it was recognized that uncontrolled inflow of contaminated water took place through the drainage outlet from a damaged drainage systemin the middle part of the wetland, where the effluent contained or could contain historical pollution from the slurry storage pond. To evaluate the efficiency of the treatment system, water samples were collected using a grab sampling technique at the inlet and outlet of the wetland, once or twice per month depending on water discharge. If water flow at the inlet was not observed, water samples were not collected.

Water samples were taken in 0.5 litre polyethylene bottles with a hermetic lid. Each water sample was marked according to the sampling place and time. Collected water samples were stored in a refrigerator under an average temperature under $5^{0} \mathrm{C}$ until delivery to the laboratory. Water samples were collected in accordance with the methodology described in the Handbook for surface water quality monitoring (Virszemes ūdenu..., 2003).

Water samples were analysed at the accredited laboratory - the Hydrochemistry Laboratory of the Latvian Institute of Aquatic Ecology according to the Latvian Standards (Table 1). As agricultural activities lead to an increased risk of nutrient losses, the concentrations of nitrogen and phosphorous compounds in the water samples were determined. Water samples were analysed for concentrations $\left(\mathrm{mg} \mathrm{L}^{-1}\right)$ of nitrate - nitrogen $\left(\mathrm{NO}_{3}-\mathrm{N}\right)$, ammonium - nitrogen $\left(\mathrm{NH}_{4}-\mathrm{N}\right)$, total nitrogen $(\mathrm{TN})$, orthophosphate - phosphorus ( $\left.\mathrm{PO}_{4}-\mathrm{P}\right)$, total phos phorus (TP) and total suspended solids (TSS).

Table 1. Analy tical methods, Latvian Standards and equipment for the chemical analy sis of water quality parameters.

\begin{tabular}{|c|c|c|c|}
\hline $\begin{array}{l}\text { Water quality } \\
\text { parameter }\end{array}$ & Latvian Standard & Analytical method & Equipment \\
\hline $\mathrm{NO}_{3}-\mathrm{N}$ & FIA, ISO 13395:1996(E) & $\begin{array}{l}\text { Flow analy sis (CFA and FIA) and spectrometric } \\
\text { detection }\end{array}$ & \multirow{3}{*}{$\begin{array}{l}\text { AutoAnalyzer } \\
\text { Bran+Luebbe AA-3 }\end{array}$} \\
\hline $\mathrm{NH}_{4}-\mathrm{N}$ & LVS ISO 7150-1:1984 & Manual spectrometric method & \\
\hline TN & $\begin{array}{l}\text { LVS EN ISO 11905- } \\
1: 1998\end{array}$ & $\begin{array}{l}\text { Method using oxidative digestion with } \\
\text { peroxodisulfate }\end{array}$ & \\
\hline $\mathrm{PO}_{4}-\mathrm{P}$ & LVS EN 1189:2000 & Ammonium molybdate spectrometric method & \multirow{2}{*}{$\begin{array}{l}\text { Spectrophotometer } \\
\text { GENESYS 10S Vis }\end{array}$} \\
\hline $\mathrm{TP}$ & LVS EN 1189:2000 & Ammonium molybdate spectrometric method & \\
\hline
\end{tabular}

In order to determine whether the nutrient concentrations measured at the inlet and outlet change statistically significant, analys is of variance (ANOVA) offered by Statis tical Package for the Social Sciences (SPSS) program was applied.

\section{RESULTS AND DISCUSSION}

Efficiency of the constructed wetland to retain nutrient compounds was determined by comparing water quality parameters at the inlet and outlet of the wetland during the study period. Results did not show a constant decrease in the concentrations of phosphorus and nitrogen compounds at each sampling event. However, average values showed a decrease for all monitored water quality parameters throughout the study period of 32 months. Table 2 summarizes the average values and standard deviations calculated for the water quality parameters at the inflow and outflow of the surface flow constructed wetland. The results of standard deviations indicate that nutrient concentrations at the inflow and outflow vary greatly. The concentrations of nitrate - nitrogen and total nitrogen decreased on average by $13 \%$. During the study period the concentrations of ammonium-nitrogen was reduced on average by $11 \%$. As described in the study of Vymazal, (2007) single stage constructed wetlands usually does not show high reduction of total nitrogen. The concentrations of orthophosphate-phosphorous and total phosphorous decreased on average by $38 \%$ and $35 \%$, respectively, and suspended solids on average by $31 \%$.

Table 2. Average, standard deviation and relative reduction values for the water quality parameters

\begin{tabular}{|l|l|l|l|}
\hline Water quality parameters & $\begin{array}{l}\text { Average concentrations at the } \\
\text { inflow, } \mathrm{mg} \mathrm{l}^{-1}\end{array}$ & $\begin{array}{l}\text { Average concentrations at the } \\
\text { outflow, } \mathrm{mg} \mathrm{l}^{-1}\end{array}$ & Relative reduction, $\%$ \\
\hline $\mathrm{NH}_{4}-\mathrm{N}$ & $0.62 \pm 1.01$ & $0.55 \pm 0.63$ & -11 \\
\hline $\mathrm{NO}_{3}-\mathrm{N}$ & $12.93 \pm 7.62$ & $11.30 \pm 5.39$ & -13 \\
\hline $\mathrm{TN}$ & $14.77 \pm 8.65$ & $12.84 \pm 5.59$ & -13 \\
\hline $\mathrm{PO}_{4}-\mathrm{P}$ & $0.18 \pm 0.41$ & $0.11 \pm 0.13$ & -38 \\
\hline TP & $0.22 \pm 0.50$ & $0.14 \pm 0.14$ & -35 \\
\hline TSS & $22.51 \pm 31.85$ & $15.60 \pm 19.65$ & -31 \\
\hline
\end{tabular}


The results of ANOVA analysis showed no statistically significant differences between the nutrient concentrations at the inflow and outflow of the constructed wetland for all measured water quality parameters if examined at a significance level of 0.05 . The greatest difference between the inlet and outlet concentrations was observed for TN with the significance level of 0.30 , followed by the concentrations of $\mathrm{NO}_{3}-\mathrm{N}$ and TSS both with the significance level of 0.33 .

It is possible that the statistical layout of the data would be closer to the normal distribution and the results would provide statistically greater reliability if the water samples would be collected proportionally to water flow. Flow proportional composite samples more accurately reflect the situation and should be preferred when it is not a long-term data set (EPA, 1982). In addition, since the research site is located adjacent to the farm yard and agricultural fields, there might be additional factors affecting the performance of the studied wetland. Study of Alvarez et al. (2008) describes the plant involvement in almost every major function within constructed wetland treatment systems. In this study the wetland has poor vegetation over the coastline slopes, which could lead the wetland function more like a sedimentation pond.

Temporal changes in the concentrations of orthophosphate - phosphorus in the constructed wetland are presented in Fig. 2. Two main factors influence $\mathrm{P}$ uptake are temperature and growth patterns (Kadlec, 2010). The concentrations of TP have increased during the cold periods in the studied wetland both at the inlet and outlet. The relation between the reduction of phosphorus compounds and the amount of suspended solids in the wetland was not pronounced. It was discovered by analysing the results both graphically and statistically.

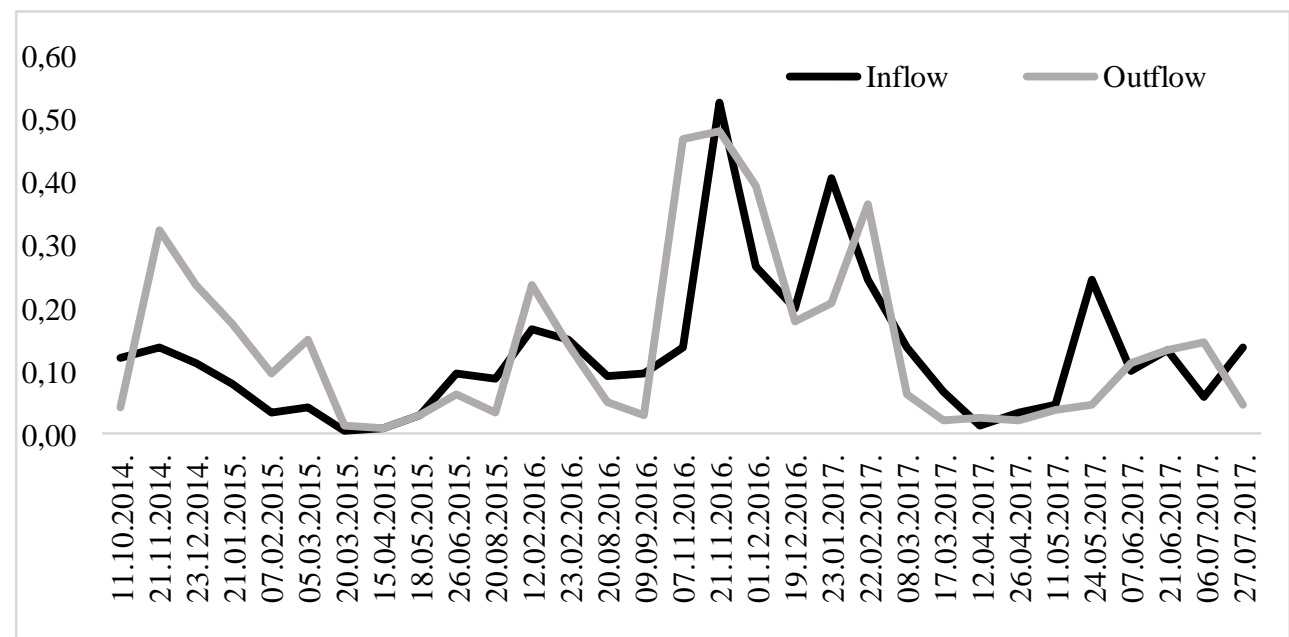

Figure 2. $\mathrm{P}_{-} \mathrm{PO}_{4}$ concentrations $\left(\mathrm{mg}^{-1}\right)$ during the study period.

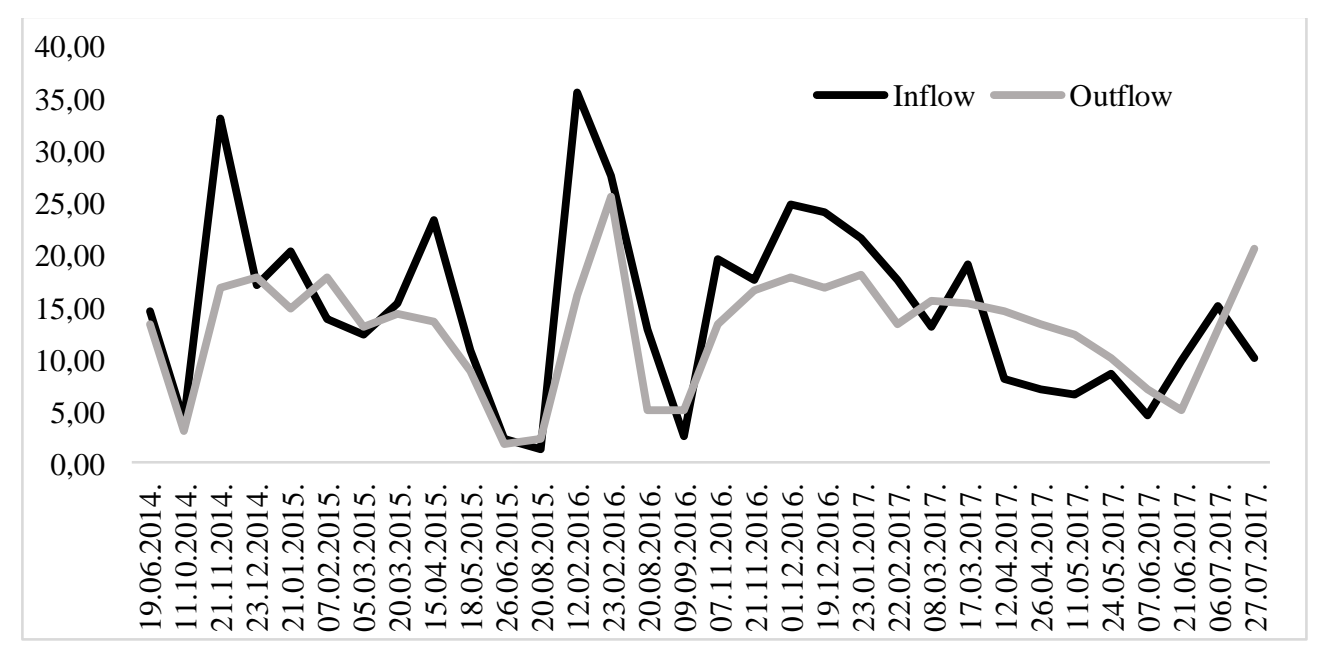

Figure 3. TN concentrations $\left(\mathrm{mg} \mathrm{l}^{-1}\right)$ during the study period.

The concentrations of $\mathrm{TN}$ at the outflow greatly depend on concentrations measured at the inlet, as showed at Fig.3. Different forms of nitrogen in water sampled at the inflow and outflow can be analysed (Wojciechowska et al, 2017). Ammonium - nitrogen entering the wetland can be transformed into nitrate - nitrogen on the way to the outlet (Xinshana et al, 2010).

Alvarez and Becares (2006) study shows that there are significant differences in the retention processes within constructed wetlands in the winter and summer periods. Average air temperature during the warm season (AprilSeptember) was $13.7{ }^{\circ} \mathrm{C}$, while during the cold season (October-March) average air temperature decreased to $1.9{ }^{\circ} \mathrm{C}$. Figure 4 shows that retention of phos phorus compounds occurred during the period from March to October when retention increased from spring to early summer. In November, December and February, the retention of phosphorus compounds was positive, which means that the concentrations of $\mathrm{P}_{-} \mathrm{PO}_{4}$ and TP increased after the wetland. Statistical analysis of 
average monthly concentrations of phos phorus compounds showed weak dependence from the month when water samples were collected. The reas on for such a low values for statistical analysis could be the fact that the winter periods in the recent years in Latvia have not been distinct. There were prolonged periods of thawing and snowless periods, so the calendar months are not interrelated with actual meteorological conditions.

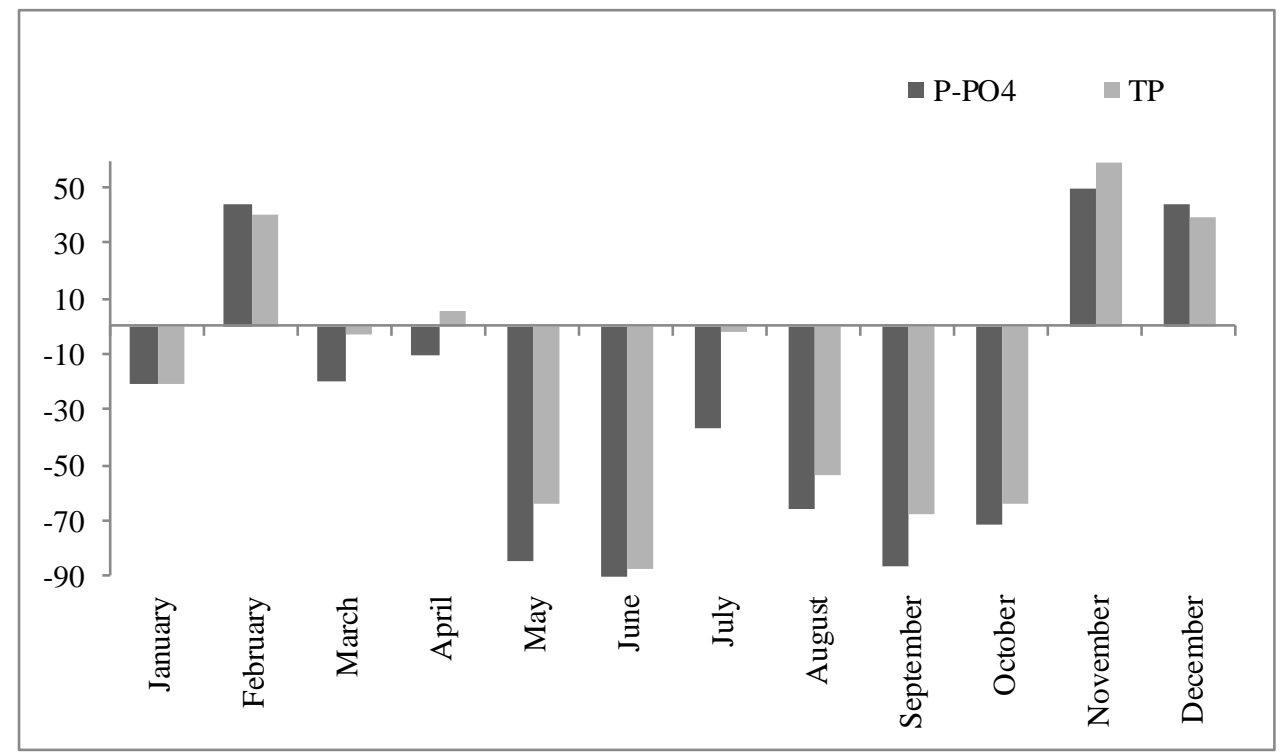

Figure 4. Average monthly retention (\%) of phosphorous compounds during the study period.

However, Figure 4 shows the relationship between $\mathrm{PO}_{4}$ and TP concentrations observed during the study period with the increase and decrease occurring in the same months with the exception of April. Similarly, a close relationship was found for $\mathrm{NO}_{3}-\mathrm{N}$ and $\mathrm{TN}$, which could be associated with transformations of nitrogen into the aquatic environment (Jakubaszek et al, 2014).

\section{CONCLUSIONS}

Surface flow constructed wetland reduced the concentrations of TN and TP on average by $13 \%$ and $35 \%$, respectively. However, in some cases, an increase in the amount of nutrients leaving the constructed wetland was observed. Higher removal efficiency for the studied wetland was observed for phosphorus compounds as phosphorus is mainly retained through physical processes such as sedimentation in the water column. Absence of plants within the wetland could be the main reason for relatively lower reduction rates for nitrogen compounds. Throughout the observation period, the concentrations of nitrogen compounds decreased on average by $11-13 \%$, the concentrations of phosphons compounds decreased on average by $35-38 \%$, and suspended solids on average by $31 \%$. In order to draw more precise conclusions about the performance efficiency of the constructed wetland, the effects of unexpected external factors shou ld be eliminated or significantly reduced.

\section{ACKNOWLEDGEMENTS}

This study was financially supported by the European Union, the European Regional Development Fund, and the Central Baltic Programme project CB295 "Practical actions for holistic drainage management for reduced nutrient inflow to Baltic Sea (NUTRINFLOW)"

\section{REFERENCES}

1. Alvarez, J. A., Becares, E. 2006. Seasonal decomposition of Typha latifolia in a free-water surface constructed wetland. Ecological engineering, Vol. 28, pp.99-105. https://doi.org/10.1016/j.ecoleng.2006.05.001

2. Álvarez, J. A., Becares, E. 2008. The effect of vegetation harvest on the operation of a surface flow constructed wetland. Water, Vol. 34, No. 5, pp.645-650.

3. Crumpton, W., Stenback, G. 2014. Annual Report on Performance of Iowa CREP Wetlands: Monitoring and Evaluation of Wetland Performance. Iowa Department of Agriculture and Land Stewardship. 10 p.

4. Deelstra, J., Iital, A., Povilaitis, A., Kyllmar, K., Greipsland, I., Blicher-Mathiesen, G., Jansons, V., Koskiaho, J., Lagzdins, A. 2014. Hydrological pathways and nitrogen runoff in agricultural dominated catchments in Nordic and Baltic countries. Agriculture, Ecosystems and Environment, Vol. 195, 211-219. https://doi.org/10.1016/j.agee.2014.06.007

5. EC. 1991. Council Directive 91/676/EEC of 12 December 1991 concerning the protection of waters against pollution caused by nitrates from agricultural sources. Official Journal of the European Communities, No. L375, pp. 1-8.

6. EPA. 1982. Handbook for Sampling and Sample Preservation of Water and Wastewater. United States Environmental Protection Agency. 418 p. 


\section{Proceedings of the $8^{\text {th }}$ International Scientific Conference Rural Development 2017}

7. Galanopolos, C., Lyberatos, G. 2016. Dy namic modelling and design of free water surface constructed wetland systems. Global NEST Journal, Vol 18, No 2, pp. 321-328.

8. Greenway, M. 2017. Stormwater wetlands for the enhancement of environmental ecosystem services: case studies for two retrofit wetlands in Brisbane, Australia. Journal of Cleaner Production, Vol. 163, pp. 91-100. https://doi.org/10.1016/j.jclepro.2015.12.081

9. Hsu, C. B., Hsieh, H. L., Yang, L., Wu, S. H., Chang, J. S., Hsiao, S. C., Su, H. C., Yeh, C. H., Ho, Y. S., Lin, H. J. 2011. Biodiversity of constructed wetlands for wastewater treatment. Ecological Engineering, Vol. 37, pp. 1533-1545. https://doi.org/10.1016/j.ecoleng.2011.06.002

10. Jakubaszek A., Wojciech M. 2014. Statistical analy sis of nitrogen in the soil of constructed wetland with horizontal sub-surface flow. Civil and environmental engineering reports, Vol. 12, Iss. 1, pp. 33-43.

11. Jordan, T. E., Whigham, D. F., Hofmockel, K. H., Pittek, M. A. 2003. Nutrient and Sediment Removal by a Restored Wetland Receiving Agricultural Runoff. Juorna. of Environmental Quality, Vol. 32, pp. 1534-1547. https://doi.org/10.2134/jeq2003.1534

12. Kadlec, R. H. 2010. Phosphorus Removal in Emergent Free Surface Wetlands. Journal of Environmental Science and Health, Part A, Vol. 40, Iss. 6, pp. 1293-1306.

13. Karklins, A. 2016. Compatibility of Latvian soil units with WRB. Proceedings of the Scientific and Practical Conference, Harmonious Agriculture, pp.49-62.

14. Keddy P. A. 2010. Wetland Ecology. Principles and conservation. Cambridge university press, No. 497 p. https://doi.org/10.1017/CBO9780511778179

15. Lagzdins, A., Jansons, V., Sudars, R., Abramenko, K. 2012. Scale issues for assessment of nutrient leaching from agricultural land in Lat via. Hydrology research, Vol. 43, pp.383-399. https://doi.org/10.2166/nh.2012.122

16. LEGMC - Latvian Environment, Geology and Meteorology Centre. 2017. Meteorology data. Available at: https://www.meteo.lv/meteorologija-datu-meklesana/?nid=461 (Accessed on 02/11/2017)

17. LGIA - Latvian Geospatial Information Agency. 2017. Online map. Available at: https://kartes.lgia.gov.lv/karte/ (Accessed on $10 / 11 / 2017)$

18. LVS EN 872. 2005. Water quality - Determination of suspended solids - Method by filtration through glass fibre filters.

19. Maynard, J. J., O'Geen, A. T., Dahlgren, R. A. 2009. Bioavailability and Fate of Phosphorus in Constructed Wetlands Receiving Agricultural Runoff in the San Joaquin Valley, California. Technical reports: wetlands and aquatic processes. Journal of Environmental Quality, Volume 38, 360-372. https://doi.org/10.2134/jeq2008.0088

20. Owenius S., van der Nat D. 2011. Measures for water protection and nutrient reduction. Project Report - Baltic Compass, Work Package $3.57 \mathrm{p}$.

21. Regulatory Act No. 600. 2014. Kārtība, kādā pieškir valsts un Eiropas Savienības atbalstu atklātu projektu konkursu veidā pasākumam "Ieguldījumi materiālajos aktīvos". Cabinet of Ministers in Latvia. [In Latvian]

22. SLS. 2014. State Land Service of Latvia. 2014. Land Report of the Republic of Latvia, Riga. State Land Service of Latvia

23. Šereš M., Hnátková T., Vymazal J., Vaněk T. 2017. Removal efficiency of constructed wetland for treatment of agricultural wastewaters. Chemistry journal of Moldova. General, Industrial and Ecological Chemistry, Vol. 12, No. 1, pp.45-52.

24. Virszemes ūdenu kvalitātes monitoringa rokasgrāmata. 2003. State Ltd. „Latvian Environment, Geology and Meteorology Centre". Available at https://www.meteo.lv/lapas/noverojumi/noverojumu-arhivs/monitoringa-rokasgramatas/monitorin garokasgramatas? $\mathrm{id}=1536 \&$ nid $=690$ (Accessed on 10/11/2017)

25. Vymazal, J. 2007. Removal of nutrients in various types of constructed wetlands. Science of the Total Environment, Vol. 380, pp. 48-65. https://doi.org/10.1016/j.scitotenv.2006.09.014

26. Vymazal J., Brezinova T. 2015. The use of constructed wetlands for removal of pesticides from agricultural runoff and drainage: A review. Environment International, Vol. 75, pp. 11-20. https://doi.org/10.1016/j.envint.2014.10.026

27. Ziverts, A. 2004. Hidrologija. Latvia University of Agriculture, Jelgava, 104.

28. Wojciechowska, E., Gajewska, M., \& Ostojski, O. 2017. Reliability of nitrogen removal processes in multistage treatment wetlands receiving high-strength wastewater. Ecological Engineering, Vol. 98, pp. 365-371. https://doi.org/10.1016/j.ecoleng.2016.07.006

29. Woods, B. B., Wilson, U,-C,H., Illman, S., Scott, T., Ashley, R., Kellagher, R. 2015. The SuDS Manual.Available https://ciria.sharefile.com/app/\#/share/view/cd2e8c7e73264402 (Aaccessed on 14/11/2017)

30. Xinshana, S., Qina, L., \& Denghuab, Y. 2010. Nutrient Removal by Hybrid Subsurface Flow Constructed Wetlands for High Concentration Ammonia Nitrogen Wastewater Procedia. Environmental Sciences, Vol. 2, pp. 1461-1468. 